\title{
Response of essential-oil yield of aromatic and medicinal plants to different harvesting strategies
}

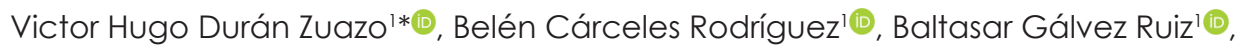 \\ Pedro Cermeño Sacristán² ${ }^{(D)}$, Simón Cuadros Tavira ${ }^{3}$, Iván Francisco García-Tejero \\ 'IFAPA Centro Camino de Purchil, Granada, Spain \\ 2IFAPA Centro Las Torres, Sevilla, Spain \\ UUniversidad de Córdoba, Córdoba, Spain \\ *Corresponding author, e-mail: victorh.duran@juntadeandalucia.es
}

\begin{abstract}
The demand for aromatic and medicinal plants (AMPs) is growing worldwide, and most of them are from the wild collection. Today there is a consensus that for industrial purposes the AMPs must be cultivated. Many studies have shown the importance of the collection strategy used to guarantee the plant regeneration, and soil protection against erosion process in mountainous areas in the Mediterranean region. In this work, during threeyear monitoring period we compared in four AMPs two harvest strategies by cutting biomass in $25 \%\left(\mathrm{BHI}_{25}\right)$ and $50 \%\left(\mathrm{BHI}_{50}\right)$ of oregano (Origanum bastetanum L.), lavender (Lavandula lanata L.); sage (Salvia lavandulifolia V.); and santolina (Santolina rosmarinifolia L.) in order to assess their effect on essential-oil content, and to be consistent with both plant and soil conservation in Mediterranean steeply sloping areas. The experimental plots were located in Lanjarón (Granada, SE Spain), on a $20 \%$ slope. According to the findings the strategy $\mathrm{BHI}_{50}$ of fresh herb of oregano, lavender, sage, and santolina produced essential-oil yield of 13.2 $\pm 1.74,17.3 \pm 1.69,9.7$

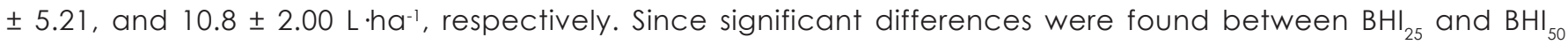
strategies for harvest and distillation of aromatic plants, we recommend a rational harvest, leaving the 50\% of the plant biomass in the field to avoid the soil degradation. In addition, with this rational harvest strategy encourages the sustainable AMP cultivation without significant alterations for essential-oil yields, and at the same time guaranteeing the regrowth, and conservation of them in its habitat. Therefore, encouragement local decision-making measures regarding environmental compatibility, social acceptability and economic viability in land use and management will be crucial. Otherwise, the inappropriate harvest of aromatic shrubs in mountain areas compromises land conservation.
\end{abstract}

Keywords: aromatic and medicinal plants, harvest strategies, essential oils, soil conservation

\section{Introduction}

The demand for aromatic and medicinal plants (AMPs), as well as for the essential oils and extracts has been expanding because of their diversified and extensive applications. Market for essential oils and plant extracts is driven by food flavouring industries, cosmetic and fragrance industries, and demand for industrial solvents (Govindasamy et al., 2011).

since ancient times, AMPs have had wide usage, and continue to be used fresh, frozen or dry, and transformed into highly usefulness products (Petrovska, 2012; Jamshidi-Kia et al., 2018; Inove et al., 2019). A vast number of AMPs comes from wild plants, although there are cultivated under conventional or organic production systems (Schippmann et al., 2006; Malik et al., 2011; Sujatha et al., 2011; Raei \& Milani, 2014). In this context, the cultivated area of AMPs in Spain is roughly $11,703 \mathrm{ha}$, most of them devoted to lavender production (ESYRCE, 2018). In 2017 according to the MAPAMA (2018), the organic cultivation of AMPs in Spain amounted to 9,168 ha, of which 527.8 ha is in Andalusia (SE, Spain). In addition, Spain is one of the largest producers of aromatic herbs and essential oil in the EU (Usano et al., 2011; Barbieri \& Borsotto, 2018). Therefore, the maintenance of aromatic shrubs and its cultivation constitute one of the important economic activities in rural areas, especially in mountain areas where other alternative crops cannot cultivate successful without irrigation.

In the last years, the total European imports of AMPs amounted to 194,000 tonnes, representing a value of $€ 694$ million. In particular, the main European suppliers of AMPs to Spain are Bulgaria, the Czech Republic, and France. Bulgaria mostly exports (wild collected) temperate AMPs. France exports a wide variety of AMPs 
for essential oil production and medicinal purposes (CBI, 2015). However, almost half of the volume of imports (49\%) was supplied by developing countries. In this context, Morocco, mainly exports to Mediterranean countries, species such as rosemary (Rosmarinus officinalis L.), while China and India export a wide variety of AMPs. Egypt is the main supplier of chamomile (Matricaria chamomilla L.) and echinacea (Echinacea purpurea L.), including a considerable variety of aromatic species. In developing countries, the demand of aromatic herbs is due to population increase and the difficulty for gain access to western medicine. By contrast in developed countries the demand of AMPs is due to the rise of alternative medicines and therapies, the development of organic farming with more natural products, avoiding the adverse side effects of synthetic drugs.

However, this growing interest in AMPs has not satisfied by augmenting the production of these plants at European level. This has caused a considerable increase in imports, mainly from overseas countries where it is possible by collection of wild plants.

In agreement to Schippmann et al. (2006) the number of species that are cultivated for commercial purposes does not exceed a few hundred, which represents less than $1 \%$ of AMPs used worldwide. On the contrary, uncontrolled wild collection means that some 15,000 aromatic species are threatened. The most serious next threats that AMPs face are the loss and degradation of their habitats, overexploitation, use of destructive harvesting techniques, and diminution or even loss of from its natural habitats (Hamilton, 1997; 2004). Therefore, the vulnerability of these plants to harvest depends fundamentally on the conservation or threat situation, the intensity and frequency of harvest, and the removed plant organ. In addition, when short harvesting turns or inadequate practices are applied, the regrowth can be affected and, consequently, the vegetation recovery.

That is, sustainable production of AMPs must be subject to their capacity to conserve the environment and especially the soil by applying adequate collection, which makes a profitable use compatible, with the conservation of the environment.

On the other hand, soil degradation is one of the most damaging effects of human activity nowadays, and it is accelerated by their actions, particularly, through farming in steeply sloping lands. In the Mediterranean Europe, where rainfall is scarce and irregular but often of high intensity, wild aromatic shrubs prevent the soil against erosivity of rainstorms (Durán et al., 2004). However, wild plant collectors sometimes indiscriminately uproot aromatic plants, leaving the soil bare and thus increasing the risk of soil erosion during torrential rains (Chand et al., 2015). In addition, the total biomass of the biota and overall biodiversity of these ecosystems are substantially reduced (Orgiazzi \& Panagos, 2018; Bach \& Wall, 2018), and the indirect improvement of the soil physical and chemical properties by the incorporation of organic matter (Pérez et al., 2010; Chen et al., 2014).

Furthermore, AMPs are important in semiarid environments for erosion control, lessen runoff and soilparticle detachment by raindrop impact. The challenge is to determine the rationale biomass harvest that would combat soil erosion and surface runoff while providing reasonable essential-oil yields. Since the wild collection of AMPs is ecologically unsuitable, and intense farming systems of mountain areas endanger soil conservation. The objective of this experiment, during three-year monitoring period was to compare four AMPs two harvest strategies by cutting biomass in 25\% $\left(\mathrm{BHI}_{25}\right)$ and $50 \%$ $\left(\mathrm{BHI}_{50}\right)$ of oregano (Origanum bastetanum L.), lavender (Lavandula lanata L.); sage (Salvia lavandulifolia V.); and santolina (Santolina rosmarinifolia L.) in order to assess their effect on essential-oil content.

\section{Material and Methods}

\section{Experimental Site}

The study was carried out in Lanjarón, a deep valley at 1,300 $\mathrm{m}$ a.s.l. running parallel to and south of the crest of the Sierra Nevada Mountains in Granada (SE Spain; UTM X: 456003.08; Y: 4088972.45). The climate is Mediterranean semiarid with irregular rainfall concentrated in autumn and winter, the average rainfall and temperature being $442,0 \mathrm{~mm}$ and $12.4{ }^{\circ} \mathrm{C}$, respectively. According to the Soil Survey Staff (2014) the soils in the study area are Typical Xerorthent with a loamy texture with 80 clay, 190 silt and $730 \mathrm{~g} \mathrm{~kg}^{-1}$ of sand, 29

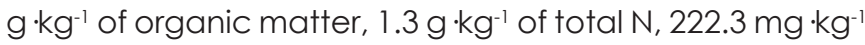

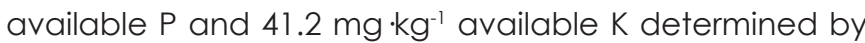
official methods for soil examination (MAPA, 1994). The precipitation and other climatic variables were measured and registered by an automatic weather station nearby to the experimental plots.

The monitoring period was conducted over a 3-year period in sixteen experimental plots $96 \mathrm{~m}^{2}$ in area (4 m x $24 \mathrm{~m}$ ) were laid out on a hillside having a $20 \%$ slope. The plots twice replicated were planted with four aromatic herbs (planting grid of $75 \times 75 \mathrm{~cm}$ ): oregano, lavender, sage, and santolina (Figure 1). Two different harvest strategies were applied by clipping the $25\left(\mathrm{BH}_{25}\right)$ and $50 \%\left(\mathrm{BHI}_{50}\right)$ of the fresh biomass. The harvest of the 
biomass was done manually at flowering stage and fresh samples were taken for determining dry matter dried at $70^{\circ} \mathrm{C}$ for 48 hours. The design was randomized blocks twice replicated per AMP and harvest strategy.

For essential-oil determination the removed plant material was air-dried at $20-22^{\circ} \mathrm{C}$ for $10-15$ days, broken up and put into cold storage $\left(-4^{\circ} \mathrm{C}\right)$ until distillation. For each sample, $200 \mathrm{~g}$ of the dried plant material was hydrodistilled for $3 \mathrm{~h}$ in a Clevenger-type apparatus, and the isolated oils were dried and stored at $4^{\circ} \mathrm{C}$.

By analysis of variance (ANOVA), the means of different effects of harvest strategy on essential-oil content of four AMPs studied were compared for the whole study period, and differences between individual means were tested using the LSD test at $p<0.05$.

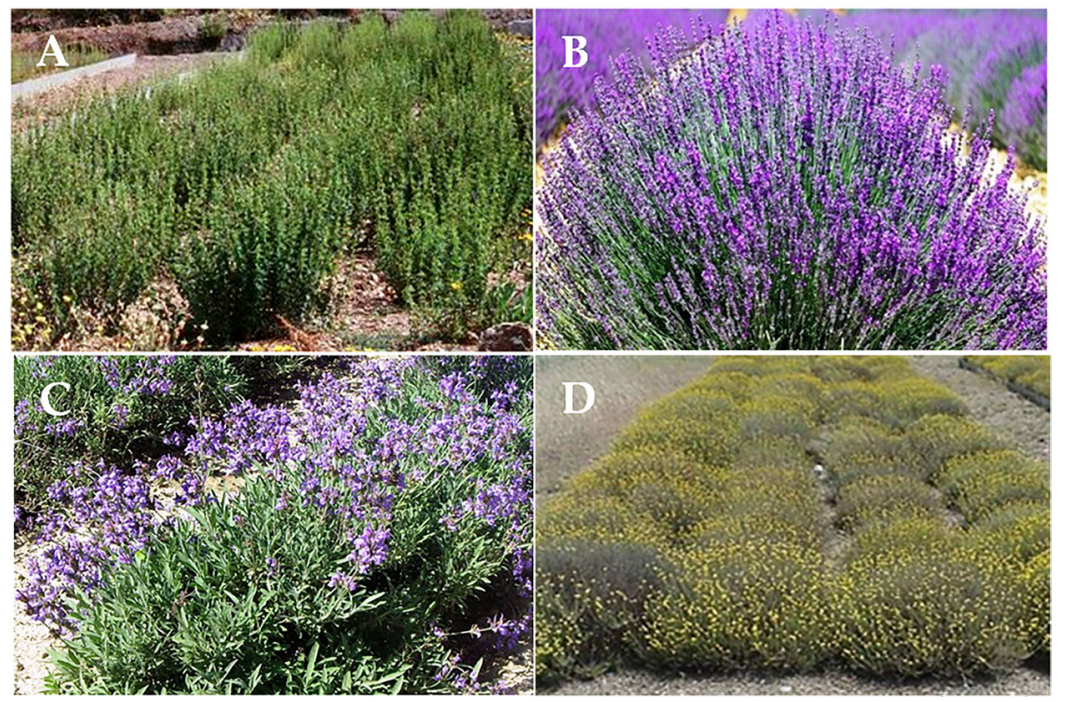

Figure 1. Experimental plots with oregano (Origanum bastetanum L.) (A), lavender (Lavandula lanata L.) (B); sage (Salvia lavandulifolia V.) (C); and santolina (Santolina rosmarinifolia L.) (D).

\section{Results and Discussion}

Essential-oil yield from AMPs

During the three-monitoring period, rainfall was typical of the Mediterranean region, being concentrated in autumn and winter. The total rainfall for the first, second, and third hydrological years was 378.0, 313.1, and 384.5 $\mathrm{mm}$, respectively. The contrasts in quantity and intensity (within and between years) of torrential rains were characterised by the discharge of important amounts of water in short periods of time that could be promoted high soil erosion rates, especially in those area without plant cover. Additionally, the rainfall in this marginal zone is crucial for rainfed farming systems because during the drought years the productivity of any type of cultivated or spontaneous vegetation is not guaranteed.

Figure 2A shows the average annual fresh biomass of AMPs in relation to harvest strategy applied during the study period, as expected an important biomass collection was for $\mathrm{BH}_{50}$ as well as denoting a variability for santolina, oregano, lavender, and sage of 6.8, 4.2, 3.7, and $1.7 \mathrm{tha}^{-1}$, respectively. By contrast the essential-oil contents followed different pattern that was found for biomass, amounting to 17.3, 13.2, 10.8, and

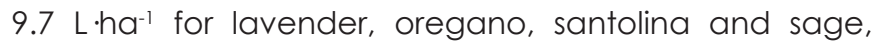
respectively (Figure $2 \mathrm{~B}$ ). For $\mathrm{BHI}_{25}$ strategy the essential- oil yield for lavender, santolina, sage and oregano was

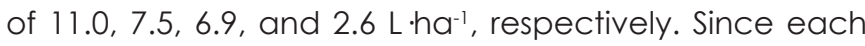
AMP has a different morphology and architecture, the biomass productions differ (sage being lower than the open, medium-sized lavender, santolina, and oregano plants).

In terms of productivity lavender was the best herb producing essential oil that differed significantly from the rest of AMPs (Table 1), and the $\mathrm{BHI}_{50}$ strategy seemed to be the most appropriate $(p<0.05)$. However, the essential oil fluctuated among the study years, being higher for third year, which coincided with the largest amount of rainfall. In this context, the water requirements among studied herbs undoubtedly are different from the more drought tolerant lavender to sensible oregano (Marulanda et al., 2007). Moreover, Chrysargyris et al. (2016) reported that water stress benefited in essential-oil contents in lavender y sage.

In general, the average essential-oil content ( $/ \mathrm{W}$ ) of studied AMPs decreased with the increased harvest intensity, in contrast to the sage shrubs (Table 2). This was presumably due to the high quantity of plant tissues containing little essential oil, and therefore provoked a dilution effect. 

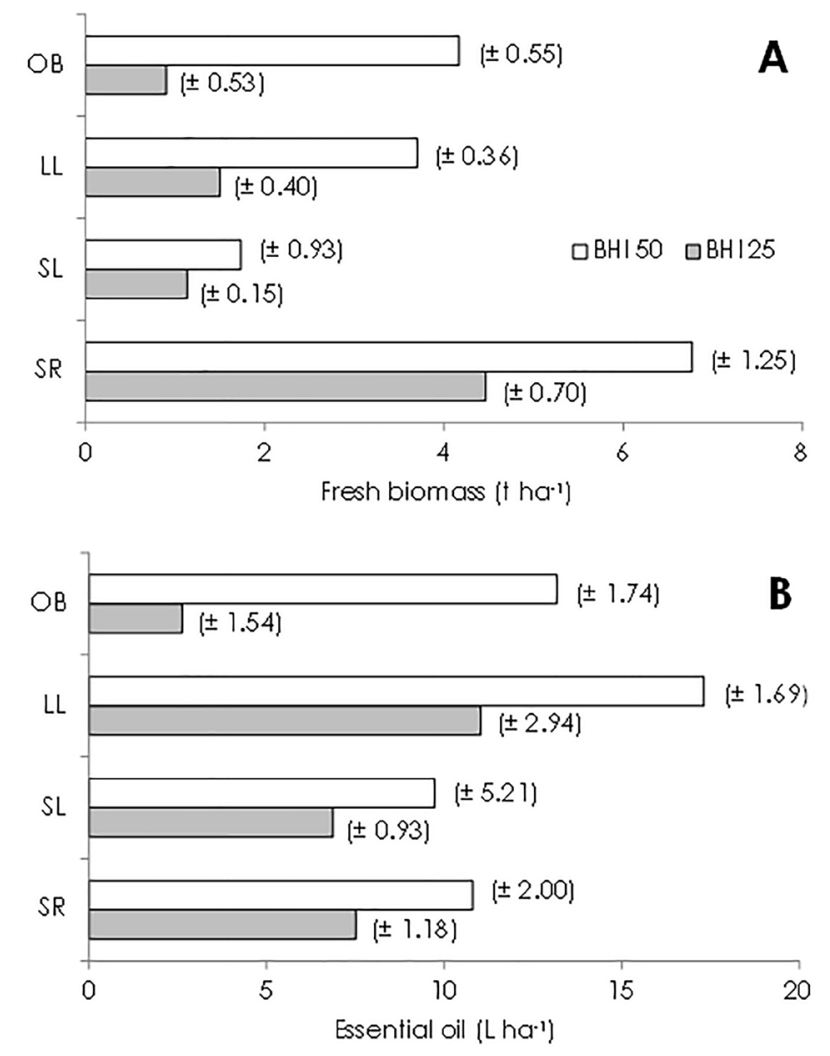

Figure 2. Average annual fresh biomass (A) and essential oil (B) yield from AMPs in response to biomass harvest intensity (BHI). OB, oregano (Origanum bastetanum L.), LL, lavender (Lavandula lanata L.); SL, sage (Salvia lavandulifolia V.); and SR, santolina (Santolina rosmarinifolia L.). Values in parenthesis are \pm standard deviation ( $\mathrm{n}$ $=24)$.

Table 1. Average essential oil yield from each AMPs.

\begin{tabular}{|c|c|}
\hline AMPs & $\begin{array}{l}\text { Essential oil } \\
\qquad\left(L \cdot h a^{-1}\right)\end{array}$ \\
\hline $\begin{array}{l}\text { Origanum bastetanum L. } \\
\text { Salvia lavandulifolia L. } \\
\text { Santolina rosmarinifolia V. } \\
\text { Lavandula lanata L. }\end{array}$ & $\begin{array}{l}7.89 a \\
8.30 a \\
9.16 a \\
14.2 b\end{array}$ \\
\hline $\begin{array}{l}\text { Biomass harvest intensity } \\
\mathrm{BHI}_{25} \\
\mathrm{BH}_{50}\end{array}$ & $\begin{array}{l}7.00 \mathrm{a} \\
12.8 \mathrm{~b}\end{array}$ \\
\hline $\begin{array}{l}\text { First } \\
\text { Second } \\
\text { Third }\end{array}$ & $\begin{array}{l}8.86 a \\
9.10 a \\
11.7 b\end{array}$ \\
\hline
\end{tabular}

The dry matter had an opposite trend to that of oil content, increasing in oregano and santolina, and decreasing for sage. Only lavender shrubs maintained invariable values of dry matter for both harvest strategies. In addition, since the biomass collected at $\mathrm{BH}_{50}$ that also included woody stems, normally with a high cellulose and lignin content, this could increase the dry biomass of shrubs. Thus, the best AMPs at any studied harvest intensity appeared to be lavender shrubs with regular biomass and essential-oil yield.
The market demand for AMPs for pharmaceutical, food, cosmetic, and perfume industries is increasing, and therefore it will be advantageous to encourage the cultivation instead of wild harvest, which can degrade marginal mountainous areas (Moré \& Colom, 2002). That is, in Spain the majority of AMPs are collected from wild resources, and most of them are traded locally and regionally rather than internationally. Also, most of the cultivation of lavender and thyme in the Mediterranean is in France and Spain (Holmes, 2016). 
The essential-oil yield values obtained in this experiment are hardly comparable with those obtained in other studies, since in general terms the high variability among studied AMPs is due to innate properties of plant species and environmental factors such as temperature, water regime, altitude, type of soil, etc. (Boira \& Blanquer, 1998; Baher et al., 2002; Curado et al., 2006; Toncer et al., 2009), therefore, this is crucial for chemical composition among aromatic herbs (D'Antuono et al., 2000; Muñoz et al., 2007). In this context, another factor that affects the yield of essential oils is the harvesting date because its contents varied according to the phenological stage in santolina (Palá et al., 2001), sage (Hashemi et al., 2013; Usano et al., 2014), lavender (Lakušić et al., 2014), and oregano plants (Toncer et al., 2009; D'Antuono et al., 2000). In addition, the extraction method used also modifies the essential-oil production and its composition as was stated by Chiasson et al. (2001) and Sefidkon et al. (2006). All these circumstances make difficult to compare the field performance values obtained with those reported by scientific literature.

According to Crespo et al. (1986) the yield in essential oil of sage (Salvia lavandulifolia subspecies oxyodon) was $1.5 \%$ that represents an intermediate richness compared to other subspecies of S. lavandulifolia and therefore, this supposes a higher yield than that attained in the present experiment for both harvest strategies. Usano et al. (2014) reported oil yields ranging between 1.30 and $2.08 \%$ for sage (Salvia lavandulifolia L.) for different harvest dates, which are also higher than those achieved in this study.

Chibani et al. (2013) reported essential oil yield of $1.4 \%$ for santolina (Santolina rosmarinifolia L.), and loannou et al. (2007) found higher oil from the leaves (1.28\%) than from the flower heads $(0.96 \%)$, in contrast with values fixed in our study. On the other hand, Palá et al. (2001) found oil yield of $1.94 \%$ for Santolina rosmarinifolia ssp. Rosmarinifolia.

Table 2. Average essential-oil content and dry matter of aromatic herbs for each harvest strategy.

\begin{tabular}{|c|c|c|c|c|}
\hline \multirow{3}{*}{ Aromatic and medicinal plants } & \multicolumn{2}{|c|}{ Essential oil } & \multicolumn{2}{|c|}{ Dry matter } \\
\hline & $\mathrm{BHI}_{25}$ & $\mathrm{BHI}_{50}$ & $\mathrm{BHI}_{25}$ & $\mathrm{BHI}_{50}$ \\
\hline & \multicolumn{2}{|c|}{$\left(\mathrm{cm}^{3} / 100 \mathrm{~g}_{D M}\right)$} & \multicolumn{2}{|c|}{$(\%)$} \\
\hline Origanum bastetanum L. & $0.82 \pm 0.54$ & $0.79 \pm 0.64$ & $36.0 \pm 2.3$ & $40.4 \pm 4.6$ \\
\hline Lavandula lanata L. & $2.10 \pm 1.85$ & $1.30 \pm 1.22$ & $35.4 \pm 4.8$ & $36.3 \pm 7.5$ \\
\hline Salvia lavandulifolia L. & $1.01 \pm 0.98$ & $1.22 \pm 0.96$ & $60.2 \pm 5.4$ & $46.2 \pm 6.8$ \\
\hline Santolina rosmarinifolia $\mathrm{V}$. & $0.41 \pm 0.34$ & $0.38 \pm 0.32$ & $41.2 \pm 8.7$ & $42.4 \pm 4.7$ \\
\hline
\end{tabular}

For lavender (Lavandula lanata Boiss) Burillo et al. (2005) obtained yields of 0.95 and $0.8 \%$, for the first two years after planting, values lower than those attained in the framework of this experiment. Barrero et al. (2008) for different vegetative stages of lavender (Lavandula lanata Boiss) collected in Sierra Nevada (Granada), fixed yields in essential oil ranging between 0.8 and $2.2 \%$. The results that have been determined in the present work are within this range.

Finally, several factors impacted on essential oil content and its composition in oregano species was pointed out by Leyva et al. (2017). That is, Baser et al. (1997) using Clevenger-type apparatus highlighted that oil content reached $1.09 \%$ from air-dried oregano herbal parts.

Harvest strategies of AMPs and its implication for soil \& water conservation

Mountain regions define some of $20 \%$ of the EU agricultural area, and in five countries- Austria, Greece, Italy, Portugal and Spain-mountain zones include more than $50 \%$ of the territory (CAP, 2016). Because mountains are particularly susceptible to land degradation, concretely soil erosion, a viable and sound land-use policy is crucial to encourage a sustainable land management and hence sustainable agricultural progression. Specifically, in SE Spain, soil erosion is a core factor in environmental degradation attributed primarily to the cultivation practices and human pressure on the land.

The lack of soil- and water-conservation measures on steeply sloping lands aggravates soil erosion. In this context, the harvest and distillation of wild aromatic plants persists as activity in Mediterranean mountainous zones. Although some AMPs are cultivated, most of them are collected, often leaving bare areas of the mountain prone to soil degradation (Durán \& Rodríguez, 2008; Romano et al., 2016). The indiscriminate uprooting of herbs augments the hazard of soil erosion and, moreover, due to the harvest timing (during the flowering stage when the seeds are not entirely developed) decreases the chance of plant regeneration. Today, it is widely accepted that the industrial use of AMPs should be based on the mechanized cultivation and selected ecotypes for yield and quality of oils or extracts as well as for cold tolerance, drought, diseases, etc. Thus, most of 
the companies prefer cultivated material, which must be certified and subjected to quality control that implies to produce properly plant material without any pollutants.

The main differences between cultivated and wild collection of AMPs are: 1) avoid the mixtures and falsifications of collected plant material; 2) homogeneous, abundant and good quality raw material, allowing a regular supply; 3 ) harvest is facilitated in many cases by mechanization that lowers costs; 4) cultivation and associated industries set up rural and specialized manpower; and 5) cultivation represents the unique only way to select and improve the implanted and cultivated plant material.

Simple conservation measures can help ensure a sustainable relationship between human and natural resources, and the use of AMPs was demonstrated as a feasible tool in this type of environment. Mountains are widely recognized as a distinct area which needs specific criteria for sustainable land use. In this line, significant reduction of erosion with oregano was reported by Rodríguez et al. (2005), with lavender shrubs (Rodríguez et al. 2009), sage and thyme (Durán et al., 2002). Durán et al. (2011) pointed out the benefits in controlling soil erosion by aromatic shrubs such as thyme, lavender, satureja, and rosemary in orchard terraces. On the other hand, according to Durán et al. (2008), the cultivation of strips of aromatic shrubs (Thymus baeticus L.) in almond orchards reduced the soil-erosion rates, this being a good example of compatibility for production of orchard crops (nuts) and ground crops (essential oils). This highlights the urgency for site-specific land-use policies as part of planned development.

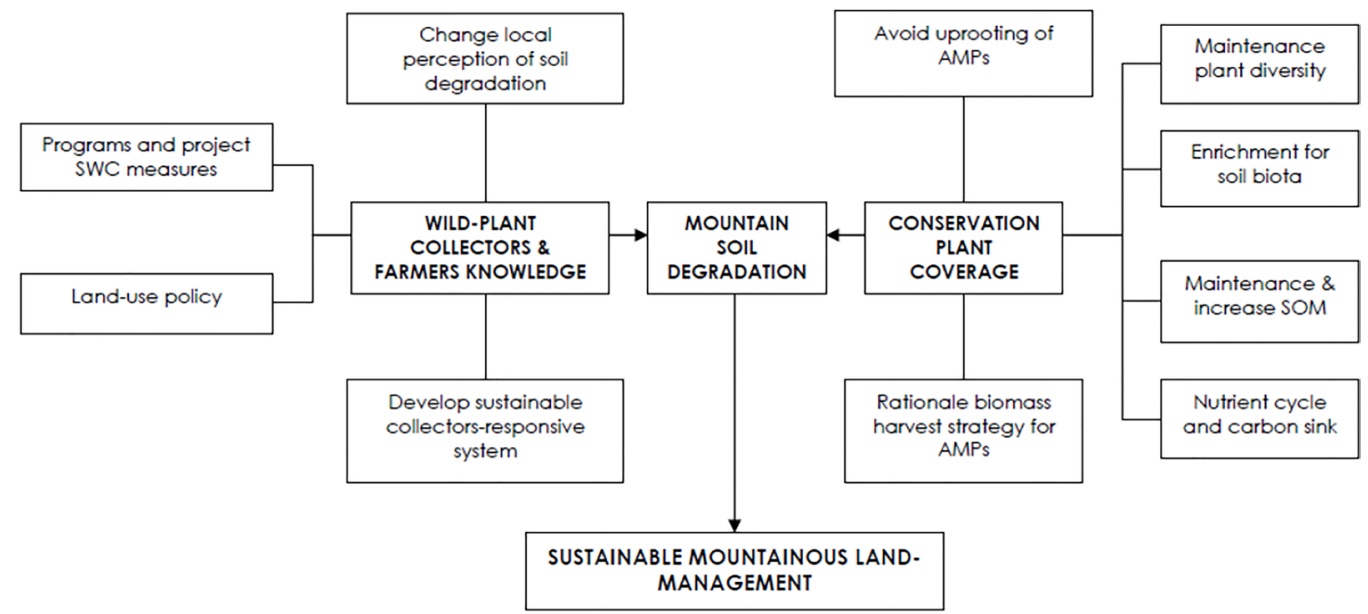

Figure 3. Biomass harvest in relation to sustainable mountainous land-management. SWC, soil and water conservation; AMPs, aromatic and medicinal plants; SOM, soil-organic matter.

The agrarian model must derive from the general model of European agriculture established in the Common Agricultural Policy (CAP, 2019). That is, a sustainable, productive agriculture, properly technified and competitive, respectful with the environment, integrating the farmers in the economic and social network of the rural environment, and keep the rural economy alive by promoting jobs in farming, agri-foods industries and associated sectors. Under these circumstances, the AMP cultivation of aromatic plants could be promising activity as an alternative economic, social, and environmentally sustainable.

Figure 3 displays the interactions among factors that could be considered to this challenge, encouraging a sustainable mountainous land-management. The implementation of this strategy would require: 1) to raise public awareness of land protection (conservation of vegetation) against degradation by soil erosion, floods, landslides, and desertification; 2) to plan an annual rotation for harvesting of AMPs, establishing the proper measures (i.e. awareness of the vegetative cycle of the different species and their possible geographical variants), and foster the cultivation of aromatic herbs, subject to the ecological principles; 3) to advance land-use policy: farm, forestry, wildlife, rangeland and recreation land; and 4) to fortify programs and projects for cooperation between regional government and local community for selecting, planning and implementing sustainable soil- and water-conservation measures. Though land degradation is a worldwide problem aggravated by climate change, solutions must be locally feasible, this being the approach of the sustainable landmanagement strategy proposed in the present work.

\section{Conclusions}

The main conclusion that may be drawn from this study is that the cultivation of plants with aromatic, medicinal, and culinary uses, and removing 50\% $\left(\mathrm{BH}_{50}\right)$ 
of the above ground biomass at harvest produces reasonable essential-oil yields for oregano, lavender, sage, and santolina of 13.2, 17.3, 9.7, and 10.8 L ha $\mathrm{h}^{-1}$, respectively. The application of this measure in cultivated as well as in wild plants could provide significant environmental and agronomic benefits. Because the inappropriate wild harvest of aromatic plants by uprooting in mountainous areas is unsustainable and compromises the soil conservation. The implantation of this strategy in harvesting the $50 \%$ of biomass could be have an important impact on soil erosion and runoff, rainfall water interception, water infiltration, and improvements of biological, physical and chemical soil properties. Because in soils of mountainous areas the shrubs provide local patches in which the combined effects of canopy and litter covers produced complex interactions that improve the micro-environment and nutrient enrichment by sequestering organic carbon.

The unsuitable harvest of AMPs and the intensity farming systems of mountain areas endanger land conservation, therefore, is an urgent need to foster sustainable measures for land management. Thus, the rational harvest of AMPs in semiarid slopes not only protected the soil against erosion and improved soil quality but also made sustainable agriculture possible. Appropriate planning for sustainable land management is a complex process because of their interaction with different sectors. This complexity demands interdisciplinary and inter-institutional co-ordination as well as an outreach system, aiming to link field information to policy making, and to raise public awareness.

\section{Acknowledgments}

Part of this publication was sponsored by the following research project: "Integrated soil and water management in rainfed almond in a context of sustainable agriculture" (RTA2017-00097-00-00) granted by INIA (National Institute for Agricultural and Food Research and Technology) and MINECO (Spanish Ministry of Economy and Competitiveness).

\section{References}

Bach, E.M., Wall, D.H. 2018. Trends in Global Biodiversity: Soil Biota and Processes. In: Dominick, A., DellaSala, M. Goldstein. I. (eds.) The Encyclopedia of the Anthropocene. Elsevier Inc., Oxford, Netherlands. 2280 p.

Baher, Z.F., Mirza, M., Ghorbanli, M., Rezaii, M.B. 2002. The influence of water stress on plant height, herbal and essential oil yield and composition in Satureja hortensis L. Flavour Fragrance Journal 17: 275-277.

Barbieri, C., Borsotto P. 2018. Essential Oils: Market and
Legislation. In: El-Shemy, H.A. (ed.) Potential of Essential Oils. IntechOpen, Rijeka, Croatia. p. 107-127.

Barrero, A.F., Herrador, M.M., Arteaga, P., Arteaga, J.F., Burillo J. 2008. Cultivars of Lavandula lanata Boiss., a good source of lavandulol. Natural Product Communications 3: 379-381.

Baser, K.H.C., Demirçakmak, B., Nuriddinov, Kh.R., Nigmatullaev, A.M., Aripov, Kh. N. 1997. Composition of the essential oil of Origanum tyttanthum Gontsch. from Uzbekistan. Journal of Essential Oil Research 9: 611-612.

Boira, H., Blanquer, A. 1998. Environmental factors affecting chemical variability of essential oils in Thymus piperella L. Biochemical Systematics and Ecology 26: 811 822.

Burillo, J., Herrador, M.M., Arteaga, P., Barrero, A.F. 2005. Comportamiento de Salvia sclarea L. y Lavandula lanata Boiss., cultivadas en Aragón como fuente de terpenos. In: Barrero, F. (ed.) Plantas iberoamericanas como fuente de terpenoides útiles en química fina. CYTED, Madrid, España. 292 p.

CAP. 2016. Context Indicators 2014-2020. https:// ec.europa.eu/agriculture/sites/agriculture/files/capindicators/context/2016/full-text_en.pdf <Access on 18 Jun. 2019>

CAP. 2019. The Common Agricultural Policy at a Glance. European Commission. https://ec.europa.eu/info/foodfarming-fisheries/key-policies/common-agriculturalpolicy/cap-glance_en\#documents<Access on $04 \mathrm{Jul}$. 2019>

CBI. 2015. Market Intelligence Product Factsheet Natural Ingredients for Health Products in Spain. https://www.cbi. eu/sites/default/files/market_information/researches/ product-factsheet-spain-natural-ingredients-healthproducts-2015.pdf<Access on 02 Jul. 2019>

Chand, S., Singh, D.V., Madhu, M., Sikka, A.K. 2015. Medicinal and aromatic plants for soil and water conservation in Nilgiris, Tamil Nadu, India: An Economic Analysis. Molecular Soil Biology 6: 1-6.

Chen, X., Song, B., Yao, Y., Wu, H., Hu, J., Zhao, L. 2014. Aromatic plants play an important role in promoting soil biological activity related to nitrogen cycling in an orchard ecosystem. Science of Total Environment 472: 939-946.

Chiasson, H., Bélanger, A., Bostanian, N., Vincent, C., Poliquin, A. 2001. Acaricidal properties of Artemisia absinthium and Tanacetum vulgare (Asteraceae) essential oils obtained by three methods of extraction. Journal of Economic Entomology 94: 167-171.

Chibani, S., Labed, A., Kabouche, A., Semra, Z., Smati, F., Aburjai, T., Kabouche, Z. 2013. Antibacterial activity and chemical composition of essential oil of Santolina rosmarinifolia L. (Asteraceae) from Algeria. Der Pharmacia Lettre 5: 238-241.

Chrysargyris, A., Laoutari, S., Litskas, V.D., Stavrinides, M.C., 
Tzortzakis, N. 2016. Effects of water stress on lavender and sage biomass production, essential oil composition and biocidal properties against Tetranychus urticae (Koch). Scientia Horticulturae 213: 96-103.

Crespo. M.E., Jiménez, J., Navarro, M.C., Zarzuelo, A. 1986. The essential oil of Salvia lavandulifolia ssp. oxyodon. A study of its vegetative cycle. Planta Medica 52: 367-369.

Curado, M.A., Oliveira, C.B.A., Jesus, J.G., Santos, S.C., Seraphin, J.C., Ferri, P.H. 2006. Environmental factors influence on chemical polymorphism of the essential oils of Lychmophora ericoides. Phytochemestry 67: 23632369.

D'Antuono, L.F., Galletti, G.C., Bocchini, P. 2000. Variability of essential oil content and composition of Origanum vulgare L. populations from a North Mediterranean area (Liguria Region, Northern Italy). Annals of Botany 86: 471478.

Durán, Z.V.H., Francia, M.J.R, Martínez, R.A. 2004. Impact of vegetative cover on runoff and soil erosion at hillslope scale in Lanjaron, Spain. The Enviromentalist 24: 39-48.

Durán, Z.V.H., Martínez, R.A., Aguilar, R.J. 2002. Control de la erosión en los taludes de bancales en terrenos con fuerte pendientes. Edafologia 9: 1-10.

Durán, Z.V.H., Rodríguez, P.C.R. 2008. Soil-erosion and runoff prevention by plant covers: a review. Agronomy for Sustainable Development 28: 65-86.

Durán, Z.V.H., Rodríguez, P.C.R., Francia, M.J.R, Martínez, R.A., Arroyo, P.L., Cárceles, R.B., Navarro, M.M.C. 2008. Benefits of plant strips for sustainable mountain agriculture. Agronomy for Sustainable Development 28: 497-505.

Durán, Z.V.H., Rodríguez, P.C.R., Martín, P.J.F., Graaff, J., Francia, M.J.R., Flanagan, D.C. 2011. Environmental impact of introducing plant covers in the taluses of terraces: implications for mitigating agricultural soil erosion and runoff. Catena 84: 79-88.

ESYRCE. 2018. Encuesta sobre Superficies y Rendimientos de Cultivos. https://www.mapa.gob.es/es/estadistica/ temas/estadisticas-agrarias/boletin2018_tcm30-504212. pdf $<$ Access on 26 Jun. 2019>

Govindasamy, R., Jehle, P., El Abidine, G.Z., Sgheir, M., El Mourid, M., Shaqir, I. 2011. Aromatic and Medicinal Plants of Tunisia: A Market Study. Journal of Food Products Marketing 17: 470-486.

Hamilton, A.C. 1997. Threats to plants: an analysis of centres of plant diversity. In: Touchell, D.H., Dixon, K.W. (eds.) Conservation into the 21 st century. Kings Park and Botanic Garden, Perth, Australia. 362 p.

Hamilton, A.C. 2004. Medicinal plants, conservation and livelihoods. Biodiversity and Conservation 13: 1477-1517.

Hashemi, S.M., Hosseini, B., Estaji, A. 2013. Chemical composition and insecticidal properties of the essential oil of Salvia leriifolia Benth (Lamiaceae) at two developmental stages. Journal of Essential Oil Bearing Plants 16: 806-816.
Holmes, P. 2016. Aromatica: a clinical guide to essential oil therapeutics. Principles and profiles. Jessica Kingsley Publishers, London, UK. 400 p.

Inove, M., Hayashi, S., Craker, E.L. 2019. Role of medicinal and aromatic plants: past, present, and future. In: Shagufta Perveen and Areej Al-Taweel (eds.) PharmacognosyMedicinal Plants. IntechOpen, Rijeka, Croatia. p. 1-13.

loannou, E., Poiata, A., Hancianu, M., Tzakou, O. 2007. Chemical composition and in vitro antimicrobial activity of the essential oils of flower heads and leaves of Santolina rosmarinifolia L. from Romania. Natural Product Research 21: 18-23.

Jamshidi-Kia, F., Lorigooini, Z., Amini-Khoei, H. 2018. Medicinal plants: Past history and future perspective. Journal of Herbmed Pharmacology 7: 1-7.

Lakušić, B., Lakusic, D., Ristić, M., Marcetic, M., Slavkovska, $\checkmark .2014$. Seasonal variations in the composition of the essential oils of Lavandula angustifolia (Lamiacae). Natural Product Communications 9: 859-862.

Leyva, L.N., Gutiérrez, G.E.P., Vázquez, O.G., Heredia, B.J. 2017. Essential oils of oregano: biological activity beyond their antimicrobial properties. Molecules 22: 989.

Malik, A.A., Suryapani, S., Ahmad, J. 2011. Chemical vs. organic cultivation of medicinal and aromatic plants: the choice is clear. International Journal of Medicinal and Aromatic Plants 1: 5-13.

MAPA. 1994. Métodos Oficiales de Análisis de suelos y aguas para riego. Tomo III Secretaria General Técnica del Ministerio de Agricultura Pesca y Alimentación, Madrid, Spain. p. 205-285.

MAPAMA. 2018. Agricultura Ecológica Estadísticas 2017. Ministerio de Agricultura y Pesca, Alimentación y Medio Ambiente, Secretaría General Técnica. http:// WWW.ccpae.org/docs/estadistiques/espanya2017. pdf<Access on 04 Jul. 2019>

Marulanda, A., Porcel, R., Barea, J.M., Azcón, R. 2007. Drought tolerance and antioxidant activities in lavender plants colonized by native drought-tolerant or droughtsensitive Glomus Species. Microbial Ecology 54: 543-552.

Moré, P.E., Colom, G.A. 2002. Distribución comercial de plantas aromáticas y medicinales en Cataluña. Investigación Agraria: Producción Vegetal 17: 43-65.

Muñoz, B.J., Arrillaga, I., Segura, J. 2007. Essential oil variation within and among natural populations of Lavandula latifolia and its relation to their ecological areas. Biochemical Systematics and Ecology 35: 479-488.

Orgiazzi, A., Panagos, P. 2018. Soil biodiversity and soil erosion: It is time to get married. Global Ecology Biogeography 27: 1155-1167.

Palá, P.J., Pérez, A.M.J., Velasco, N.A., Palá, P.R., Sanz, J., Conejero, F. 2001. Seasonal variation in chemical constituents of Santolina rosmarinifolia L. ssp. rosmarinifolia. Biochemical Systematics and Ecology 29: 663-672. 
Pérez, B.A., Mataix, S.J., Zornoza, R., Guerrero, C., Arcenegui, V., Mataix, B.J., Cano, A.S. 2010. Influence of plant species on physical, chemical and biological soil properties in a Mediterranean forest soil. European Journal of Forest Research 129: 15-24.

Petrovska, B.B. 2012. Historical review of medicinal plants' usage. Pharmacognosy Reviews 6: 1-5.

Raei, Y., Milani, A.M. 2014. Organic cultivation of medicinal plants: a review. Journal of Biodiversity and Environmental Sciences 4: 6-18.

Rodríguez, P.C.R., Durán, Z.V.H., Francia, M.J.R., Martínez, R.A., Cárceles, R.B. 2005. Evaluación de la erosión y contaminación bajo diferentes intensidades de recolección con cubiertas de orégano (Origanum bastetanum L.) en Lanajaron (SE España). Edafologia 12: 53-64.

Rodríguez, P.C.R., Durán, Z.V.H., Martínez, R.A., Francia, M.J.R., Cárceles, R.B. 2009. High reduction of erosion and nutrient losses by decreasing harvest intensity of lavender grown on slopes. Agronomy for Sustainable Development 29: $363-370$.

Romano, G., Lahmer, F.Z., Palasciano, M.A., Lamaddalena, L., Gentile, F. 2016. Soil erosion control with different plant configurations in Mediterranean environment. ASABE, Annual International Meeting 162460165.

Schippmann, U., Leaman, D., Cunningham, A. B. 2006. Comparison of cultivation and wild collection of medicinal and aromatic plants under sustainability aspects. In: Medicinal and Aromatic Plants. Bogers, R.J., Craker, L.E., Lange, D. (eds.), Springer, Dordrecht, Netherlands. 312 p.

Sefidkon, F., Abbasi, K., Khaniki, G.B. 2006. Influence of drying and extraction methods on yield and chemical composition of the essential oil of Satureja hortensis. Food Chemistry 99: 19-23.

Soil Survey Staff. 2014. Keys to Soil Taxonomy, $12^{\text {th }}$ ed. USDANatural Resources Conservation Service, Washington DC, USA. file://C:/Users/duran/Downloads/2014_Keys_to_ Soil_Taxonomy.pdf<Access on 02 Feb. 2019>

Sujatha, S., Bhat, R., Kannan, C., Balasimha, D. 2011. Impact of intercropping of medicinal and aromatic plants with organic farming approach on resource use efficiency in arecanut (Areca catechu L.) plantation in India. Industrial Crops and Products 33: 78-83.

Toncer, O., Karaman, S., Kizil, S., Diraz, E. 2009. Changes in essential oil composition of oregano (Origanum onites L.) due to diurnal variations at different development stages. Notulae Botanicae Horti Agrobotanici Cluj-Napoca 37: 177-181.

Usano, A.J., Herraiz, P.D., Cuadrado, O.J., Benito L.B., Sánchez, R.O., Palá, P.J. 2011 . Ecological production of lavenders in Cuenca province (Spain). A study of yield production and quality of the essential oils. Botanica Complutensis 35: 147-152.

Usano, A.J., Palá, P.J., Santa-Cruz, R.M., Herráiz, P.D. 2014.
Chemical description and essential oil yield variability of different accessions of Salvia lavandulifolia. Natural Product Communications 2: 273-276.

Conflict of Interest Statement: The authors declare that the research was conducted in the absence of any commercial or financial relationships that could be construed as a potential conflict of interest.

All the contents of this journal, except where otherwise noted, is licensed under a Creative Commons Attribution License attribuition-type BY. 